This work is licensed under a Creative Commons Attribution 4.0 International License.

Ovaj rad dostupan je za upotrebu pod međunarodnom licencom Creative Commons Attribution 4.0.

https://doi.org/10.31820/f.32.1.8

Martina Petranović

\title{
SCENOGRAFIJA U KAZALIŠNIM ADAPTACIJAMA ROMANA NEDJELJKA FABRIJA
}

dr. sc. Martina Petranović, Odsjek za povijest hrvatskog kazališta Zavoda za povijest hrvatske književnosti, kazališta i glazbe Hrvatske akademije znanosti i umjetnosti, Zagreb, martina_petranovic@yahoo.com

izvorni znanstveni članak UDK 821.163.42.09Fabrio,N-31 792.2(497.5)"19"

rukopis primljen: 1. listopada 2019; prihvaćen za tisak: 20. veljače 2020 .

Rad se bavi scenografskim čitanjima kazališnih uprizorenja romana Nedjeljka Fabrija na primjerima predstava Vježbanje života u režiji Georgija Para i izvedbi Hrvatskoga narodnog kazališta Ivan pl. Zajc u Rijeci, Berenikina kosa u režiji istoga redatelja $i$ izvedbi Hrvatskoga narodnog kazališta u Zagrebu, te Smrt Vronskoga u režiji Ivice Boban i izvedbi Hrvatskoga narodnog kazališta Ivan pl. Zajc u Rijeci. Scenografije spomenutih predstava oblikovali su istaknuti hrvatski scenografi Zlatko Kauzlarić Atač (Vježbanje života, 1990., Berenikina kosa, 1995.) i Dalibor Laginja (Smrt Vronskog, 1995.), bitno pridonijevši kazališnoj transpoziciji romana na scenu.

Ključne riječi: scenografija; oblikovanje svjetla; adaptacija; Nedjeljko Fabrio; Zlatko Kauzlarić Atač; Dalibor Laginja

U razgovoru koji je 2008. godine Jozefina Dautbegović vodila s Nedjeljkom Fabrijem povodom sedamdesete obljetnice njegova rođenja, Fabrio je na njezino pitanje „Što vam se prvo pojavi kad pišete: slika, riječ, zvuk...?" nedvosmisleno odgovorio da mu u procesu pisanja najprije dolazi 
slika, „slika koju se slijedi” i koja se potom, uzmogne li se, raspisuje na nekoliko stotina stranica romana (Fabrio u Dautbegović 2008: 7). U svome je bogatom i raznovrsnom književnom opusu Nedjeljko Fabrio uspješno „slijedio" više takvih slika i od sredine osamdesetih godina prošloga stoljeća do početka novoga milenija ispisao jedinstven romaneskni korpus koji broji četiri djela, romane Vježbanje života (1985), Berenikina kosa (1989) i Triemeron (2002) okupljene u tzv. Jadransku trilogiju, te Smrt Vronskoga (1994), roman posvećen Domovinskome ratu. Od spomenutih su naslova čak tri romaneskne „slike” Nedjeljka Fabrija uspješno adaptirane za kazalište i (likovno) otjelotvorene na scenama dviju hrvatskih nacionalnih kazališnih kuća.

Već od najranije dobi zatravljen teatrom, Fabrio je u hrvatskome kazalištu obnašao različite uloge i funkcije, od pasioniranoga gledatelja (napose kada je riječ o opernim predstavama) preko dramaturga i dramskoga autora čija su dramska djela u kazalištu izvođena još na mijeni šezdesetih i sedamdesetih godina 20 . stoljeća, ${ }^{1}$ do kazališnoga kritičara, kroničara i povjesničara. Njegovo je posljednje autorsko djelo u kazalištu bio libreto za balet Maestro nadahnut životom i djelom skladatelja Borisa Papandopula, praizveden 2006. godine u Hrvatskome narodnom kazalištu u Zagrebu. Kazališnopovijesno gledano, međutim, daleko najveći scenski uspjeh i izvanscenski odjek ipak su imale rečene scenske adaptacije triju Fabrijevih romana koji su tijekom prve polovice devedesetih godina 20. stoljeća pretočeni u zapažene, a u pojedinim slučajevima, i kultne kazališne predstave: Vježbanje života praizvedeno 27. veljače 1990. godine u Hrvatskome narodnom kazalištu Ivana pl. Zajca u Rijeci, Berenikinu kosu praizvedenu 24. veljače 1995. u Hrvatskome narodnom kazalištu u Zagrebu i Smrt Vronskoga praizvedenu 12. svibnja 1995. također u Hrvatskome narodnom kazalištu Ivana pl. Zajca u Rijeci. Predstave Vježbanje života i Berenikina kosa režirao je Georgij Paro prema scenskim prilagodbama što su ih za te prigode načinili Darko Gašparović (Vježbanje života) i sam Nedjeljko Fabrio (Berenikina kosa) koji je vlastito romaneskno štivo zapravo pretočio

1 Važnije izvedbe dramskih djela Nedjeljka Fabrija obuhvaćaju Reformatore praizvedene 29. veljače 1968. u Hrvatskome narodnom kazalištu Ivana pl. Zajca u Rijeci, dramu Čujete li svinje kako rokću u ljetnikovcu naših gospara? praizvedenu 20. veljače 1970. u produkciji Hrvatskoga narodnog kazališta Ivan pl. Zajc iz Rijeke u Narodnom kazalištu u Zadru te dramu Meštar praizvedenu 4. studenog 1971. u Studentskom eksperimentalnom kazalištu iz Zagreba na pozornici zagrebačkoga Teatra ITD. Nakon sloma Hrvatskoga proljeća Fabrio je zbog tematike svojih dramskih djela i u njima zastupljenih političkih i ideoloških stavova do devedesetih godina 20. stoljeća bio kazališno rijetko izvođen autor. 
u izvorno dramsko djelo pisano za zagrebački HNK i posvećeno redatelju Georgiju Paru, ${ }^{2}$ a predstava Smrt Vronskoga izvedena je u adaptaciji i režiji Ivice Boban. U svim su spomenutim uprizorenjima romana Nedjeljka Fabrija važnu interpretativnu ulogu odigrala i scenografska rješenja, kako Zlatka Kauzlarića Atača za Vježbanje života i Berenikinu kosu, tako i Dalibora Laginje za Smrt Vronskoga, bitno pridonijevši kazališnoj transpoziciji Fabrijevih romana na scenu što će se u nastavku radu nastojati i pokazati.

S obzirom na središnju fabulativnu okosnicu Fabrijeva prvog romana ispredenu oko društvenog i privatnog života hrvatskih i talijanskih obitelji na jadranskoj obali u dugom vremenskom periodu od gotovo stoljeća i pol te velik broj događaja, prostora, likova i društvenopovijesnih mijena te na piščevu namjeru da romanom ocrta kulturnu, duhovnu i društvenu klimu kao i povijest jednoga grada i jednoga šireg zemljopisnog podneblja i mentaliteta, već je od samoga početka rada na postavljanju Vježbanja života bilo izvjesno da će primjereno oblikovanje scenskoga prostora biti jedan od strukturnih i ishodišnih problema predstave odnosno rješavanja inscenacije romana. Zlatko Kauzlarić Atač se u svojim prethodnim radovima, mahom iz osamdesetih godina 20. stoljeća, nametnuo kao scenograf zahtjevnih pa i spektakularno oblikovanih kazališnih adaptacija proze u kojima je likovno nadahnutim, dramaturški funkcionalnim i simbolički izražajnim scenografijama u suradnji s redateljima spretno rješavao panoramske prikaze, rastvaranja i brze izmjene raznolikih prizor(išt)a (primjerice, M. Krleža, Banket u Blitvi, 1981.; M. Crnjanski, Roman o Londonu, 1988.), posebice se istaknuvši scenografskom suradnjom s redateljem Georgijem Parom.

U međuprostoru osobnoga autorskog iščitavanja Fabrijeva romana kojim je bio neskriveno oduševljen, Parovih redateljskih traganja za odgovorom na pitanja kako prikazati „vremenski protok od stoljeća i po” i „prizvati duh raznih epoha” (Paro 1990: [28]), piščeve ideje o zasnovanosti predstave na dva tlocrta, „na onom užem - tlocrtu obitelji, i na onom širem - tlocrtu grada (urbsa), i u našem slučaju grada države" (Fabrio 1990: 11) te uvjerenosti dramaturga Darka Gašparovića da su obitelj i grad dvije ključne romaneskne slike (Gašparović 1990: 23) iskristalizirala se i Atačeva temeljna scenografska vizija za riječko uprizorenje Vježbanja života. Bila je to vizija „sobe-grada” (Kauzlarić Atač u Leković 1990: 3), jedinstvenoga

2 U razgovoru povodom premijere Georgij Paro istaknuo je da je Berenikinu kosu „Fabrio za HNK u Zagrebu pisao kao posebno djelo, kao dramu baš za HNK u Zagrebu." (Paro u Bašić 1995: 12). 
scenskog prostora koji je istodobno i soba i grad, intimni prostor obiteljskih scena i tzv. male povijesti pojedinca koliko i javni prostor društvenih i političkih previranja i tzv. velike povijesti koja se prelama preko leđa jedinke, saževši u sebi i temeljne odrednice romana, režije i predstave. Kasnije je, u retrospektivnim osvrtima na svoja scenografska djela, tu istu sobu Z. Kauzlarić Atač nazivao i „sobom povijesnoga propuha”, sobom kroz koju povijest prolazi, ili možda točnije rečeno, sobom koju je povijest pregazila. ${ }^{3}$ Štoviše, razmišljajući o najprikladnijem scenografskom rješenju za inscenaciju Fabrijeve spektakularne društvenopovijesne panorame, i na metaforičnoj i simboličnoj razini, i na razini njezine praktične scenske provedbe, Atač je načinio prostor koji izranja iz morskoga plavetnila, a istovremeno je uronjen i u kamenje i gromače karakteristične za razmatrano podneblje (Atačeve scenske gromače dijelom su se nadovezivale i na prepoznatljive gromače s Glihina svečanoga kazališnog zastora na premijernoj izvedbi Vježbanja života.), a sobu je oslikao vedutama ${ }^{4}$ grada. U izvedbenome je pogledu Atačeva soba-grad bila oblikovana kao kulisa od tri zida na kojima su obrisi grada i povijesnoga brodovlja naslikani Atačevim osobnim i prepoznatljivim slikarskim rukopisom kakav spomenuti autor i inače nastoji unijeti u svoja scenografska ostvarenja, dodatno premrežujući svoje slikarsko ishodište sa scenografskim radom. Naposljetku, Atačevo nadovezivanje na vlastita slikarska počela pa i ishodišta, kao i bijeg od doslovnoga preslikavanja zbilje, osjeća se i u materijalu od kojega je scenografija bila realizirana u prostoru, a to je poliester, čime je načinjen priključak na jedan od tipičnih i omiljenih materijala skupine Biafra unutar koje je Atač stupio na likovnu scenu sedamdesetih godina 20. stoljeća. Štoviše, i skulpture koje su za pojedine scene korištene u predstavi (spomenik bana Jelačića, spomenik Josipa Broza, palma i sl.) također su bile načinjene od poliestera, a oblikovali su ih studenti zagrebačke likovne akademije pod mentorstvom kipara Mire Vuce, biafranca i Atačeva kolege i prijatelja. Uvođenje poliestera kao materijala za izvedbu kulisa i predmeta u prostoru dodatno je odmaknulo scenografiju od realističke ili iluzionističke impostiranosti, premda je prema potrebama radnje, dakako, temeljna scenska konstrukcija prazne sobe nadopunjavana karakterističnim pokućstvom i uporabnim

3 Razgovor Z. Kauzlarića Atača i autorice teksta vođen je u studenome 2018. godine.

4 U tom je pogledu zanimljivo istaknuti i misao Danijele Bačić Karković o metonimijskoj i metaforičnoj ulozi „vedutizma” kao „algorijsko-simbolične pozadine ispričanih pripovijesti” u Fabrijevim djelima (Bačić Karković 2008: 27). 
predmetima (stol, sat, pijanino...). U scenografijama koje su prethodile i slijedile scenografiju za Vježbanje života Atač se rado poigravao s povijesnim zastavama vezanim za radnju izvođenoga dramskog djela, nerijetko prekrivajući scenu ili dio scene velikim platnenim zastavama, a ovdje je posegnuo za dodatnom nadgradnjom scene oslikavši sobu-grad bojama riječke povijesne zastave (crvena, žuta, plava), pri čemu je modrom bojom prizivao i ugođaj morskoga plavetnila, a žutom i dojam starinskih gradskih razglednica. Atačevo pozivanje na boje riječke zastave bio je, dakako, postupak čvrsto povezan sa sadržajem i idejama predstave posvećene složenim i zapretanim međuodnosima kulturnih i nacionalnih identiteta $u$ kojoj su zastave i grbovi bili „simbolski nositelji značenja” (Gašparović 2012: 136) i indikatori brojnih smjena vlasti i promjena odnosa moći u povijesti Rijeke i njene okolice, ${ }^{5}$ a istodobno je snažno korespondirao i s pluralizmom i polifonijom jezičnoga sloja predstave (hrvatski, talijanski, njemački, mađarski).

Za potrebe brzog i jednostavnog smjenjivanja individualne i kolektivne povijesti, obiteljskih drama i društvenopolitičkih povijesnih prevrata, intimnih komornih scena i masovnih prizora skupne igre $s$ većim brojem izvođača, Atač je na stražnji zid sobe postavio i velika dvostruka vrata te dvoja bočna vrata/prozor kroz koja u predstavu provaljuju i velika povijesna događanja i male ljudske sudbine, i kolektivna sjećanja zajednice i privatna sjećanja pojedinca, u krajnosti oličene vojnim povorkama, paradama ili demonstracijama s jedne te svadbenim svečanostima, rođenjima, sahranama ili intimnim susretima s druge strane. Spomenutim stražnjim otvorom Atač je na materijalnoj razini dobivao otvaranje drugoga plana scenske igre pa su se prema potrebama radnje u dubini scene smjenjivali prizori, primjerice, morske obale, obiteljske grobnice, i slično, dok je na metaforičnoj razini istodobno ostvario ideju spominjanoga "povijesnoga propuha” i Fabrijevih stavova o "histeriji historije” i povijesti kao „jalovosti, ludilu i smrti”, odnosno nepresušnom izvoru ljudskoga stradanja i patnje. Atačeva scenografija računala je i na suigru prostora, kulise i scenske rasvjete, funkcionalnu u prijelazima iz prizora u prizora i pretapanjima prizora, a nadasve simboličnu u podcrtavanju atmosfere prizora. Osim dubinskoga

5 Darko Gašparović navodi da se u predstavi izmjenjuje „sedam zastava: carska habsburška, banska hrvatska, austrijska, mađarska, riječka, talijanska i socijalistička jugoslavenska. Nedostaju osma, francuska, i današnja hrvatska, iz jednostavnog razloga, što ne ulaze u povijesno vrijeme obuhvaćeno u romanu i dramatizaciji" (Gašparović 2012: 136). 
usložnjavanja izvedbenoga prostora na prednji i stražnji plan umnogome upravo karakterističnoga za Atačev scenografski rukopis, kao što je to uostalom i ovdje također provedeno objedinjavanje eksterijera i interijera, scenografsko rješenje Z . Kauzlarića Atača redatelju i golemom scenskom ansamblu sastavljenom od oko stotinu i pedeset izvođača (članova Hrvatske i Talijanske drame, orkestra, zbora i baleta Opere, studenata dislociranoga studija glume u Rijeci te gostiju iz tršćanskoga kazališta) nudilo je i mogućnost dinamiziranja scenske radnje po vertikali te je tako velik broj scena, bilo komplementarnih bilo kontrapunktiranih događanjima na glavnoj sceni/prosceniju, odigran na podiju podignutom iznad kulise sobe-grada, kao njihova dopuna, nastavak ili komentar. Na gornjem nivou odvijale su se, primjerice, prostorno dislocirane scene (zbivanja na palubi parobroda, na Jelačićevu trgu ili na ratištu), služio je kao govornica s koje su se tijekom predstave plasirale različite političke ideje (govor Frana Supila, pjevanje partizanskih pjesama...), a na njemu su se odvijali i viševrsni nadrealni prizori ili prizori iz snoviđenja (alegorijski prikaz smrti/ anđela u liku preminule Fanice), kao i plesni i glazbeni prizori, poglavito važni imajući u vidu zamjetan udio glazbe koja u predstavi sažima, poentira i uokviruje sva scenska zbivanja. Prostorno rješavanje predstave time, međutim, nije iscrpljeno, već su prema potrebama radnje, napose za scene teatra u teatru (skidanje mađarske zastave u kazalištu, Mussolinijev govor u kazalištu), povremeno korištene i pojedine kazališne lože, čime je prostorom izvedbe obuhvaćeno i samo gledalište, donekle modificirajući fokus gledanja predstave i stvarajući dojam totalnoga teatra. Predstava Vježbanje života bila je, kao što znamo, veliki kazališni i društveni događaj, prerastavši okvire grada Rijeke, ${ }^{6}$ a svoj je zasluženi amblemski status nedvojbeno stekla i zahvaljujući Atačevom scenografskom čitanju - i Fabrijeva romana, i (povijesti) grada Rijeke.

Vježbanje života inscenirano je kao spektakularna ansambl predstava kakve su u to doba, dakako s različitim poticajima, ishodima i recepcijom, obilježile repertoar ne samo riječkoga kazališta (usp. Cuculić 2004) nego i drugih hrvatskih nacionalnih kazališnih kuća, napose Hrvatskoga narodnoga kazališta u Zagrebu u kojem je realizirana i sljedeća kazališna adaptacija Fabrijeva romana, Berenikina kosa. Ona je, međutim, već u svome

6 Za 2020. godinu riječki HNK Ivana pl. Zajca predviđa predstavu pod nazivom Vježbanje života - drugi put koja nakon trideset godina kani izvedbeno razmotriti i kultni status čuvene predstave iz 1990. godine. 
polazištu i temeljnoj ideji, unatoč istome autorskome timu predstave koji je stajao i iza Vježbanja života i iza Berenikine kose - redatelj Georgij Paro, scenograf Zlatko Kauzlarić Atač, kostimografkinja Marija Žarak - ipak već u začetku odustala od spektakularnosti Vježbanja života i realizirana je kao komornija predstava s ponešto konvencionalnijim tretmanom scenskoga prostora (te se izvedba zadržala isključivo na prostoru pozornice), no u kojoj je, neovisno o posve drukčijoj impostaciji predstave u odnosu na slavnu prethodnicu, scenografija ponovno imala ne samo nadasve funkcionalan već, naime, i likovno iznimno razveden udio. Štoviše, pišući osvrt na Berenikinu kosu kazališna kritičarka Marija Grgičević ustvrdila je da bi usporedba dviju predstava također ukazala na „razvitak plodne suradnje redatelja i pisca, te likovnih i glazbenih koautora u moglo bi se reći produbljivanju značenja i učinaka jedne u punom suglasju s piščevom rečenicom usvojene i modificirane scenske forme" (Grgičević 1995: 31). U istom je osvrtu Marija Grgičević, međutim, navela i nepodudarnosti između dvije predstave, lociravši ih u prvom redu među razlike u duhovoj klimi iz koje je svaka od predstava poniknula, no budući da je Vježbanje života okarakterizirano kao „kronisterija”, a Berenikina kosa kao „Familienfuge” inicijalno inscenacijsko razmimoilaženje dviju predstava zasigurno se treba tražiti već u usmjerenjima svakog od Fabrijevih predložaka.

Kao što je u Berenikinoj kosi fokus Fabrijeva interesa povijest dviju obitelji, hrvatske obitelji Gorma i talijanske obitelji Ziani, uhvaćenih u žrvanj globalnih povijesnih političkih, ideoloških i nacionalnih odnosa i mitologija na prostoru jadranskoga priobalja u rasponu od stotinjak godina, tako je i rodoslovno stablo dviju obitelji velikim dijelom postalo okosnica, kralježnica, objedinjujuća slika ili provodni motiv (na tragu Fabrijeva posezanja za glazbenim strukturnim i kompozicijskim elementima $\mathrm{u}$ narativnom oblikovanju Berenikine kose) Atačeva scenografskoga rješenja: središnja, repetitivna i najzapaženija slika Atačeve scenografije za Berenikinu kosu nedvojbeno je bilo postavljanje osvijetljenih obiteljskih portreta i rodoslovnih stabala na crni horizont u dubini pozornice. Atačevo rodoslovno stablo koje sublimira ideju Fabrijeva romana, međutim, nije bilo zamišljeno kao tek atraktivna likovna pozadina već i kao dramaturški aktivan i lirski nabijen odašiljatelj značenja u suigri sa scenskim svjetlom, pa su stoga osvijetljeni portreti nakon smrti nekog od likova, a u konačnici nakon zatiranja obiteljske loze, polako i doslovno trnuli, brišući osobe/ obitelji i s povijesnog i s kazališnog obzora. Spomenuta scenografska slika stajala je također i u stanovitoj svezi s naslovom romana/dram(atizacij)e/ 
predstave koji simbolički asocira i na zvjezdano nebo odnosno zviježđe na Sjevernome nebu, pa i s ulogom (zvjezdanoga) neba na scenskome horizontu u dubini pozornice kao nositeljem ugođaja i lirskim/dramskim komentarom scenskih zbivanja.

Slijedom dramskih prizora koji prate životni tijek dviju obitelji i nekolicine pojedinaca od sredine 19. do sredine 20. stoljeća, u scenografskom su se pogledu također nizala viševrsna rješenja za mnoštvo prostora i razdoblja što su se prelijevala iz jednoga u drugi, oslanjajući se na jedinstveni prostorni dispozitiv i značenja odabranih scenskih elemenata: prazan prostor na prosceniju na kome se izmjenjuju komadi scenski neophodnoga mobilijara, povišena pozornica podij $s$ nekoliko stuba $u$ stražnjem dijelu scene, oslikano nebo na horizontu u dubini scene. Osnovni se prostor dodatno modificirao i obogaćivao kombinatorikom elemenata tipičnih za pojedini prizor te varirao različitim pozicijama zaokretne pozornice, spuštanjem (crkva) ili razmicanjem (vlak) scenskih paravana ispred kojih se odvijala scenska igra i pomacima dijela povišene pozornicepodija po dubini scene unaprijed ili unatrag. Pretapanja ili prelasci iz jedne scene u drugu često su ostvarivani upravo pomoću scenografije i oblikovanja scenskoga svjetla, primjerice zamračivanjem i osvjetljavanjem pojedinih dijelova scene ili zamračivanjem stražnjeg plana uz spuštanje crnoga horizonta. Atačev uvriježeni scenografski rukopis stoga se može uočiti u spomenutim tehničkim rješenjima, višeplanskome kadriranju scene po dubini i visini, brzim izmjenama prizora pomoću nekoliko osnovnih scenografskih elemenata i igre scenografije i scenske rasvjete, prepoznatljivim lajtmotivima (npr. bijelo rublje izvješeno na konopima cijelom širinom i/ili dubinom pozornice) te na različite načine oslikanim ali redovito simbolički intoniranim nebom na horizontu koje se modificira od prizora do prizora $i$ na kojem se u suglasju s radnjom uvijek nešto događa oblikujući osnovne ugođaje prizora ili ukazujući na preokrete u zbivanjima (bijeli oblaci na modrome nebu, duga, svitanje, sumrak, zvjezdano nebo...). Likovnome ugođaju i scenskoprostornoj praktičnosti ukupnoga dojma scenografije pridonijelo je i Atačevo rješenje prizora u kazalištu gdje kazališnu garderobu dočarava pomoću nekoliko nizova obješenih kazališnih kostima. Sklonost likovnoj simbolici i poetičnosti, ali i nadovezivanje na vlastita slikarska istraživanja motiva pasije, žrtve i raspeća (Križni put, 1986; Pad, 1989) pa i njihovo povezivanje $s$ nacionalnom tragedijom $\mathrm{i}$ ratnim stradanjima Hrvatske u Domovinskome ratu tijekom prve polovice devedesetih ( $\mathrm{Na}$ pragu 21. stoljeća, 1992), prepoznatljivo je i u završnome prizoru predstave 
u kojem scenografsko jedro i stradanje na brodu dobivaju simboliku raspela i stradanja na križu kao alegorije pasije pojedinca i naroda u vrtlogu povijesti, a čemu pridonosi i završni akord predstave u kojem se u formi molitve prizivaju stihovi iz Kranjčevićeva Mojsija („Izvedi narod moj o Gospode"). Atačeva scenografija za Berenikinu kosu, drugim riječima, omogućila je ne samo scenskoprostornu organiziranost nego i metaforičnu zaokruženost oplemenjujući je poetičnošću likovnoga izraza, pa u apostrofiranju Atačevih specifičnih priloga ovoj izvedbi Fabrija na sceni možda napose treba izdvojiti njegovu prepoznatljivu sklonost vizualnome pripovijedanju, komentiranju, sažimanju i nadgradnji priče tijekom izmjena niza scenografskih prizora od podizanja do spuštanja zastora, gotovo na tragu vizualnoga kazališta ili čak stvaranja likovne „formule za redatelje”, kako se jednom prigodom o Atačevoj scenografiji izrazio Antun Celio Cega (Celio Cega, 1995). Ono što je na kraju Berenikine kose i redateljskim zahvatom (završna molitva) i scenografskim činom (jedro - križ) donekle naznačeno - stradanje Hrvatske u Domovinskome ratu - u sljedećoj (i zasad posljednjoj) predstavi rađenoj prema nekom od romana Nedjeljka Fabrija, predstavi Smrt Vronskog, dovedeno je u samo središte pozornosti, i tekstom N. Fabrija u adaptaciji Ivice Boban, i režijom I. Boban, i scenografskim, odnosno u širem smislu vizualnim oblikovanjem predstave: autor scenografije je, kako je rečeno, Dalibor Laginja, no ne treba zaboraviti ni oblikovatelja svjetla i projekcija Denija Šesnića, ni autora video projekcija Krasimira Gančeva (kao, dakako, ni autorice kostima Iku Škomrlj i Danicu Dedijer te maski Miljenka Sekulića), čiji su prinosi u predstavi Smrt Vronskog gotovo neodvojivi od koncepta i provedbe scenografskoga rješenja scenskoga prostora i predstave u cjelini.

Imajući u vidu Fabrijevo intertekstualno tematsko povezivanje problematike Domovinskoga rata u Hrvatskoj s motivima iz Tolstojeva romana Ana Karenjina i dovođenje Tolstojeva Vronskoga u središte hrvatsko-srpskoga ratnog sukoba, koje je u predstavi dodatno naglašeno scenama između Vronskoga i Karenjine, u scenskoprostornom oblikovanju predstave prisutan je stanovit dualizam između kronotopskih odrednica kraja 19. i kraja 20. stoljeća, napose u prvome dijelu predstave, ali je tome ipak velikim dijelom „doskočeno” kostimografskim sredstvima, kao što je kostimografski monumentalno riješen i nadrealan fantazmagorični sloj predstave u kojem se pojavljuju likovi iz staroslavenske mitologije. Nadograđivanjem pak predstave brojnim igranim i dokumentarnim projekcijama slika i video isječaka o Domovinskome ratu i pretvaranjem 
predstave ne samo u kazališni spektakl na tragu repertoarnoga zaokreta riječkoga kazališta u devedesetima (Vježbanje života, Umorstvo u katedrali) o kojem je već bilo govora (Cuculić 2004), već i u multimedijalni spektakl koji umnogome obilježava vizualnoakustična igra utemeljena na mogućnostima moderne kazališne tehnologije ali i sinergiji više umjetničkih disciplina, $u$ predstavi je dodatno naglašeno i amplificirano pa i dovedeno do središnjega organizacijskog načela predstave Fabrijevo postmodernističko spajanje dokumentarnog i fikcionalnog, karakteristično za svu njegovu romanesknu prozu. Polazeći od jednoga Fabrijeva citata koji pisac smatra programatskim i u kojemu se referira na moć mehaničke slike kao ratnoga svjedoka i na potrebu umjetnosti da „iz sebe, gramatikom vlastita života, pripovijeda o ratu i o zločinima" (Fabrio 1995: [16]), Ivica Boban predstavu je izgradila na multimedijalnom suodnosu scenske igre i projiciranih isječaka pozivajući se u dramaturškom i redateljskom postupku na, kako sama bilježi, postojeća „iskustva Eisensteinove montaže atrakcija, kazališna iskustva postmoderne, te neka iskustva filmske i video elektronske montaže" (Boban 1995: 17).

Scenografov prinos tako naznačenom redateljskom postupku bio je viševrsan, a u prvome je redu podrazumijevao dinamičan suodnos scenografije s dramaturgijom teksta i predstave. Uostalom, već od samoga ulaska u prostor hrvatske kazališne scenografije krajem osamdesetih godina 20 . stoljeća, Dalibor Laginja nametnuo se kao scenograf kojemu ne odgovara tip kazališta u kojem su predstava, pa i scenografija, podređeni tekstualnome predlošku ili pukoj realizaciji redateljske ideje, već teatar u kojem postoji kreativna sloboda scenografa i svih suradnika, u kojem važno mjesto imaju slika, zvuk ili pokret, pa i u kojem slika može biti polazište kazališnoga čina (Laginja u Šegota Lah 2006: 105). Predstava se stoga može čitati i kao niz efektnih scenografskih slika u živom dijalogu s ostalim komponentama predstave, a napose svjetlom i projekcijama: eksperimentiranje s novim tehnologijama u smislu otvaranja prostora i aktivnoga, integralnog i konstitutivnog udjela videa i scenske rasvjete u oblikovanju scenografije bit će jednom od kontinuiranih obilježja scenografskoga rada Dalibora Laginje, nerijetko u savezništvu s oblikovateljem svjetla Denijem Šesnićem, partnerom i na ovoj predstavi.

U skladu sa spomenutim navodom iz Fabrijeva teksta, predstavu je scenografski otvorio prikaz uvećanoga objektiva/leće, a potom i unošenje TV prijemnika na scenu, sugerirajući od samog početka sadržajnu i formalnu usmjerenost predstave ka svojevrsnom svjedočenju, medijskom 
prikazu i multimedijskom pristupu, koliko i obnavljajući prizore iz zbilje u kojima je sjedenje uz TV prijemnike i pomno praćenje najnovijih vijesti iz ratom zahvaćenih područja bila svakodnevnica. Uvođenje objektiva/leće unekoliko je podudarno i s repetitivnim, gotovo opsesivnim slikarskim motivom Dalibora Laginje, ikonikom kruga, svojevrsnim okom koje sve vidi, lećom koja pomiče granice unutrašnjeg i vanjskog ili umnožava perspektive (usp. Todorović u Šegota Lah 2006: 93).

Idući važan provodni motiv scenografije u prvom dijelu predstave bio je i vlak koji Laginja najprije uvodi kao trodimenzionalnu dječju igračku, a potom preoblikuje u plošnu i pojednostavljenu kulisu vagona (podiže se i spušta na scenu prema potrebama radnje) koja dinamizira i razdjeljuje prostor po dubini i visini te ispred koje se, iza koje se i na kojoj se odvijaju različiti scenski prizori, od retrospekcije preko scenske zbilje do fantazmagorije, a koja na koncu opredmećuje doslovnu smrt jedne ljubavi i metaforički označuje početak jednoga uništenja. U drugome pak dijelu predstave, čvršće usredotočenom na fikcionalizaciju i dokumentiranje zbivanja iz Domovinskoga rata, Laginja kulisu vlaka zamjenjuju sugestivnim znakovima i tragovima vojništva, ratišta te materijalne, fizičke i duhovne ratne devastacije kao što su barikade, limene bačve, golemi top, ostaci pougljenjenih drvenih krovišta spaljenih kuća, razoreni bolnički zid, devastirana palača s kristalnim lusterom spuštenim na pod iz pozorničkoga nadstroplja, gotovo beckettovski intonirano ogoljelo stablo na čijim su granama umjesto lišća zapele tek plastične vrećice, križ..., a scenski prisutni elementi dopunjeni su projekcijama i rasvjetom. Projekcije (s) kojima je scenografija intenzivno komunicirala i koje su stajale u čvrstom međuodnosu s igranim prizorima na sceni, bile su i dokumentarnoga karaktera i simboličke rekonstrukcije, a njihova je uloga manjim dijelom imala značenje proširivanja prostora igre a većim simboličkoga podcrtavanja i oblikovanja atmosfere, primjerice, u prijetećem projiciranju neprijateljskih insignija, $u$ potresnom i preciznom evidentiranju razmjera ratnih razaranja i stradanja ili u kontrastnim lirskim prizorima. Ističući kako je rijetko kada na hrvatskoj kazališnoj sceni vidio „tako snažno ostvarenu multimedijalnost”, kritičar Dalibor Foretić je u osvrtu na predstavu stoga mogao nadodati i sljedeće: „Scenografija Dalibora Laginje ne gradi autonomnu metaforičnost, nego se u izvrsno iznađenim fragmentima savršeno uklapa u cjelovitu sliku u kojoj interferira sa sjajno ostvarenim video projekcijama Krasimira Gančeva (naročito majstorskim u nekim intimnim prizorima Ane i Vronskoga), impresivnom rasvjetom Denija Šesnića, precizno ostvarenim 
kostimima Danice Dedijer i Ike Škomrlj, maskama Miljenka Sekulića [...]. Scenska slika se lelujavo pretače iz jednoga prizora u drugi, stalnim radom fona scene koji se vrtoglavo ubacuje u prve planove. Nije to samo igra da zablješti oči nego iz nje stalno izbija smisao, asocijacija, metafora." (Foretić 1995: 19) S Foretićevom pohvalnom ocjenom scenografije i njezinih brojnih semantičkih potencijala složila se većina kazališnih kritičara koji su pisali o predstavi (primjerice, Boris B. Hrovat i Želimir Ciglar), a svojevrstan presedan ili barem iznimku u pisanju o kazališnim predstavama načinila je povjesničarka umjetnosti, buduća autorica monografije o Daliboru Laginji, Nataša Šegota Lah, napisavši osvrt u cijelosti posvećen vizualnome aspektu predstave Smrt Vronskog. U tekstu pod naslovom „Općeljudska ikonografija paklene simfonije" autorica je ustvrdila da je vizualna komponenta predstave "najsuvremenije, najdojmljivije i najpotresnije iskazan aspekt sagledavanja ratne drame” i da je „interpretativna čistoća slike i transparentnost tragedije" postignuta upravo scenografskim rješenjima Dalibora Laginje (Šegota 1995: 15), a plasirala je i tezu o Laginjinoj scenografiji kao likovnoj instalaciji. Potonju je misao autorica produbila desetak godina kasnije i u monografskom prikazu Laginjina stvaralaštva iz 2006. godine zaključila: „Laginjina interpretacija Smrti Vronskog jest slika, umjetničko djelo velikih dimenzija koje se smjestilo na pozornici i slijedi sudbinu predstave, jer se dramaturški otvara i zatvara u ritmu kazališnog zastora i po potrebi vremena za vraćanjem na ovu priču." (Šegota Lah 2006: 34) Opravdanost tako usmjerenih čitanja Laginjinih scenografskih ostvarenja potvrdit će i redatelj Ozren Prohić s kojim je Laginja nekoliko puta plodno scenografski surađivao, no redatelj će, razumljivo, ipak naglašenije apostrofirati uklopljenost Laginjine scenografije u kazališnu predstavu inzistirajući na Laginjinom „promišljanju scenografije kao trodimenzionalne slike, slike u prostoru koja se dinamizira drugim elementima scenskoga čina" (Prohić u Habjan i Žeželj, ur. 2012: [85]). Takvom je zaključku najbliže i određenje Laginjine scenografije u riječkoj inscenaciji Fabrijeve Smrti Vronskog.

U kazališnim uprizorenjima romana Nedjeljka Fabrija, kako je vidljivo, scenografska rješenja Zlatka Kauzlarića Atača (Vježbanje života, Berenikina kosa) i Dalibora Laginje (Smrt Vronskog) bila su dramaturški i likovno važan akcent u realizaciji i scenskome sklapanju cjelovite vizije predstave, a $s$ obzirom na ovjeren konstitutivni i stilotvorni udio scenografije u sve tri predstave nije sasvim neopravdano reći ni da je upravo scenografsko prepoznavanje i likovno uobličavanje duha Fabrijeve uvodno spominjane „slike” zabilježene i raspisane na stranicama njegovih romana umnogome 
zaslužno za scenski uspjela čitanja Fabrijevih romana. Tvrdnja se čini dodatno utemeljenom i stoga što je riječ o autorskim radovima dvojice scenografa koji su u svome radu polazili s pozicije naglašene uvjerenosti u vrijednost scenografije kao cjelovite i zaokružene umjetnine te u umjetničku samosvojnost scenografskih tumačenja predstave i (pre)oblikovanja i aktualiziranja tekstualnoga predloška, naravno, u čvrstoj sprezi s cjelinom i intencijom svake pojedine predstave.

\section{Literatura}

Bačić Karković, Danijela (2008) "Očevi i sinovi u Fabrija", Književna republika, 6, 5-7, 23-31.

Bašić, Stanko (1995) „Redatelj sam koji poštuje tekst (razgovor s Georgijem Parom)", Slobodna Dalmacija, 52, 15870, 24. veljače, 12.

Boban, Ivica (1995) „O dramaturškom i redateljskom postupku”, Smrt Vronskog (programska knjižica), Hrvatsko narodno kazalište Ivana pl. Zajca, Rijeka, [17-18].

Botić, Matko (2013) „Kolo oko Fabrija; tri romana Nedjeljka Fabrija u novim životima na kazališnim daskama”, Igranje proze, pisanje kazališta, Hrvatski centar ITI, Zagreb, 158-169.

Celio Cega, Antun (1995), „Zlatko Kauzlarić Atač”, http: //www.ns-dubrava. hr/2226-zlatko_kauzlaricatac_1995/ Posjet 29. rujna 2019.

Cuculić, Kim (2004) „Od nacionalnih budnica do iskoraka u kazališni eksperiment (kazalište u Rijeci 1987 - 2004), Kolo, 14, 4. http: // www.matica.hr/kolo/294/od-nacionalnih-budnica-do-iskoraka-ukazalisni-eksperiment-kazaliste-u-rijeci-1987-2004-20159/ Posjet 24. rujna 2019.

Dautbegović, Jozefina (2008) „Stidim se zbog nedostatka njihova stida. Razgovor s Nedjeljkom Fabrijem", Književna republika, 6, 5-7, 3-19.

Fabrio, Nedjeljko (1990) „Riječ dvije Nedjeljka Fabrija”, Vježbanje života (programska knjižica), HNK Ivana pl. Zajca, Rijeka, 10-11.

Fabrio, Nedjeljko (1995) „Pripovjedač piše svojim kazalištarcima”, Smrt Vronskog (programska knjižica), Hrvatsko narodno kazalište Ivana pl. Zajca, Rijeka, [15-16].

Foretić, Dalibor (1995) „Neujednačena paradigma rasapa”, Novi list, 49, 130, 15. svibnja, 19. 
Gašparović, Darko (1990) „O ljubavi i odlasku”, Vježbanje života (programska knjižica), HNK Ivana pl. Zajca, Rijeka, 23-24.

Gašparović, Darko (2012) „Nedjeljko Fabrio”, Dubinski rez, Hrvatski centar ITI, Zagreb, 109-159.

Grgičević, Marija (1995) „S vertikalom molitve”, Večernji list, 39, 27. veljače, 31.

Habjan, Stanislav; Žeželj, Danijel ur. (2012) Pozornice. Katalog izložbe scenografija Dalibora Laginje, HNK Ivana pl. Zajca, Rijeka.

Leković, Koraljka (1990) „Una vecchia cartolina ingiallita”, La Voce del popolo, 45, 27. veljače, 3 .

Paro, Gorgij (1990) „Pitanja unedogled”, Novi list, 44, 56, 27. veljače, [28].

Šegota, Nataša (1995) „Općeljudska ikonografija paklene simfonije”, Novi list, 49, 134, 19. svibnja, 15.

Šegota Lah, Nataša (2006) Dalibor Laginja, Adamić, Rijeka.

\section{SUMMARY}

Martina Petranović

SCENOGRAPHY IN STAGE ADAPTATIONS OF NEDJELJKO FABRIO'S NOVELS

The paper focuses on the scenography in stage adaptations of Nedjeljko Fabrio's novels, i.e. on the scenography of Zlatko Kauzlarić Atač in Vježbanje života (Practicing Life) directed by Georgij Paro in the Croatian National Theatre Ivan pl. Zajc in Rijeka (1990), and in Berenikina kosa (The Berenice's Hair) also directed by Georgij Paro in the Croatian National Theatre in Zagreb (1995), and the scenography of Dalibor Laginja in Smrt Vronskog (The Death of Vronsky) directed by Ivica Boban in the Croatian National Theatre Ivan pl. Zajc in Rijeka (1995). The scenography of each mentioned stage adaptation is meticulously analysed and studied in terms of its general ideas and practical outputs, its functions in the theatre production, its relation towards the individual production elements, its place in the designer's opus, and its critical reception. The study reveals that the analysed designs contributed significantly to the stage adaptations of Fabrio's novels by articulating Fabrio's ideas and concepts, material and metaphorical transposition of production's ideas, utilising, organising and modelling stage space, dramaturgical functionality, as well as visual expressiveness and effectiveness of the production.

Key words: scenography; light design; adaptation; Nedjeljko Fabrio; Zlatko Kauzlarić Atač; Dalibor Laginja 